\title{
Effect of natural antioxidants on the stability of ostrich meat during storage
}

\author{
By Esmat A. Abou-Arab and Ferial M. Abu-Salem
}

\author{
Department of Food Technology, National Research Centre, Dokki, Cairo, Egypt \\ ( ${ }^{\star}$ Corresponding author: ferial_mas@yahoo.com)
}

\section{RESUMEN}

Efecto de antioxidantes naturales en la estabilidad de carne de ostra durante su almacenamiento

La carne de ostra es cada vez más popular en todo el mundo. El objetivo de este estudio fue evaluar el efecto de diferentes antioxidantes tales como el ácido ascóbico (AA), el $\alpha$-tocoferol (Toc) y hierbas de romero (ROS) en la estabilidad de la carne de ostra durante el almacenamiento. La composición química de la carne de ostra mostro un contenido bajo en grasa (1.5\%) en combinación con un alto contenido de proteínas (22.4\%). Las combinaciones de AA + Ros, Toc + Ros y AA + Toc fueron las más efectiva en la reducción de los valores de ácido tiobarbitúrico (TBA) y de peróxidos. Los antioxidantes muestran un insignificante efecto en la acidez como ácido oleico. La adicción de AA, Toc y Ros mostro una mejora de la estabilidad del color de los filetes de ostra, es más, el tratamiento combinado fue más efectivo en la estabilidad del color. En conclusión, la adicción de AA, Toc y Ros tuvo un efecto positivo en el aroma, rancidez y decoloración de la carne refrigerada de ostra.

PALABRAS CLAVE: Antixidantes - Carne de ostra - Estabilidad - Hierba de romero.

\section{SUMMARY}

Effect of natural antioxidants on the stability of Ostrich meat during storage

Meat from the ostrich is becoming increasingly popular throughout the world. The aim of the current study was to evaluate the effects of different antioxidants such as ascorbic acid (AA), $\alpha$-tocopherol (Toc) and rosemary herb (Ros) on the stability of ostrich meat during storage. The chemical composition of ostrich meat showed low fat content $(1.5 \%)$ combined with high protein content $(22.4 \%)$. The combination of AA + Ros, Toc + Ros and AA + Toc was more effective in reducing the thiobarbituric acid (TBA) and peroxide values. The antioxidant showed insignificant effects on acidity as oleic acid. The addition of the efficient role of $\mathrm{AA}$, Toc and Ros showed an improvement in the color stability of ostrich steaks and the combined treatment was more effective in color stability. In conclusion, the addition of AA, Toc and Ros had a positive effect on aroma quality, rancidity and discoloration of refrigerated ostrich meat.

KEY-WORDS: Antioxidants - Ostrich meat - Rosemary herb - Stability.

\section{INTRODUCTION}

The ostrich (Struthio Camelus) is the largest of all birds and belongs to the order of ostrich breeding, a long-developed industry in South Africa which has also spread to Australia, North America and more recently to European countries (Sales, 1996). Ostrich meat is becoming increasingly popular throughout the world. The healthy red meat of ostrich makes them very important for many livestock industries. Meat is highly vulnerable to oxidative changes which result in the development of off-flavor and rancidity. Lipid oxidation is the major factor in reducinges the quality and acceptability of meat and fat products (Morrissey et al., 1998). Color changes in cooked products during refrigerated storage have been linked to oxidation phenomena. Several factors have been reported including the characteristics and amount of fat, the packaging and the presence of antioxidants (Jo et al., 2000).

In recent years, researchers have focused on the potential role of dietary antioxidants in promoting health and reducing the risk of heart disease, cancer, cataracts, and other degenerative diseases related to aging (IMFN, 2000). Exogenous antioxidants can be used to prolong shelf-life and ensure the quality of products. Numerous studies have indicated that lipid oxidation may be controlled or at least minimized through the use of antioxidants (Escalante et al., 2003). The addition of antioxidants to processed meats is often carried out to counteract the negative effects of processing aids. However, due to the concerns about the toxicological safety of synthetic antioxidants, it may be desirable to replace these conventional antioxidants with natural antioxidative substances (Chen et al., 1992). Some vitamins, particularly vitamin $A$ in the form of betacarotene, vitamin $\mathrm{C}$ in the form of as ascorbic acid and vitamin $E$ in the form of tocopherols and tocotrienols, function as independently active natural dietary antioxidants (IMFN, 2001). In recent years, many researchers have evaluated the antioxidant properties extracted from different plant extracts (Ibanez et al., 2003). Rosemary is a popular Labiatae herb with a verified potent antioxidant activity. The 
antioxidant activity of rosemary is mainly related to phenolic diterpenes which are considered effective free-radical scavengers (Dorman et al., 2003).

The aim of the present study was to evaluate the effect of natural antioxidants (vitamins C, E and rosemary herb) on the stability of refrigerated ostrich meat steaks during storage.

\section{MATERIALS AND METHODS}

\subsection{Materials}

Ostrich meat was obtained from the Egyptian Company of Ostrich breeding, Cairo, Egypt.

\subsection{Chemicals}

All chemical as well as L-ascorbic acid and DL$\alpha$-tocopherol were purchased from Sigma Chemical Co. (St. Louis, MO, ISA). All chemicals used were "Analar" grade.

Rosemary powder (Rosmarinus officinalis) was obtained from the Medicine Plant and Agriculture Seeds Haraz Co., Cairo, Egypt.

\subsection{Preparation of ostrich steaks meat}

Steaks from lliofibularis $(1.5 \mathrm{~cm}$ in thickness) were removed from the ostrich carcasses (5-samples) that had been stored at $4{ }^{\circ} \mathrm{C}$ for 1 day after slaughter. The steaks were treated by dipping for $10 \mathrm{~min}$ in the following treatments: (1) the control samples, (2) samples treated with $0.05 \% \mathrm{~L}$-ascorbic acid (AA), (3) samples treated with $0.08 \% \mathrm{DL}-\alpha$-tocopherol (Toc) and emulsifier (lecithine), (4) Rosemary powder samples (5g ) prepared with $100 \mathrm{ml}$ water (to obtain $0.05 \%$ rosemary extract), other samples dipped in a mixture containing both as follows: (5) samples treated with $0.05 \%$ L-ascorbic acid $+0.08 \%$ DL- $\alpha$ tocopherol, (6) samples treated with $0.05 \% \mathrm{~L}$-ascorbic acid $+0.05 \%$ rosemary and (7) samples treated with $0.08 \%$ DL- $\alpha$-tocopherol $+0.05 \%$ rosemary. All samples were packaged in plastic film under vacuum and stored at $4{ }^{\circ} \mathrm{C}$. Chemical, microbiological and sensory evaluations were carried out on all samples at $0,7,14$ and 21 days of storage.

\subsection{Chemical analysis}

The mean of three replicates of each test was recorded. Moisture, protein and ash were determined according to AOAC (1995). Fat was extracted according to the method described by Bligh and Dyer, (1959). Thiobarbituric acid (TBA) was colorimetrically measured as $\mathrm{mg}$ malonaldehyde/ $\mathrm{Kg}$ as mentioned by Okayama (1987). Peroxide value (PV) was determined according to the method of AOAC (1995). The free fatty acids of the extracted fat (as \% of oleic acid) were determined according to Pearson (1968). Meat pigments were measured as metmyoglobin \% (Met Mb) according to the method described by Zaika et al., (1976). The mean of three replicates of each test was recorded.

\subsection{Microbiological analysis}

The viable bacterial count of ostrich meat samples was carried out according to Okayama (1987).

\subsection{Sensory evaluation}

A sensory evaluation of raw and cooked (for 10 min.) ostrich steaks (about 15-20g) was performed according to the method described by Djenane et al., (2002). Scores from the evaluation were recorded by ten trained panelists under the suitable conditions of light and temperature. "Odor" scores assigned to the intensity of off odors associated to meat spoilage: 1 $=$ none, $2=$ slight, $3=$ smell, $4=$ moderate and $5=$ extreme. In the determination of odor, samples were smelled immediately after cooking. Discoloration of uncooked meat scores referred to percentage of discolored surface: $1=$ none, $2=0-10 \%, 3=$ $11-20 \%, 4=21-60 \%$, and $5=61-100 \%$. Results were expressed as the predominant score given by panelists.

\subsection{Statistical analysis}

Data were subjected to statistical analysis using computerized analysis of variance and Duncan's multiple range test procedures with SAS (1998).

\section{RESULTS AND DISCUSSION}

The results of the chemical composition of ostrich meat are presented in the current study (Table 1). These results indicated that ostrich meat had low fat content $(1.5 \%)$ and high protein content $(22.4 \%)$ based on wet weight. The percentage of moisture and ash were found to be 75.0 and $1.1 \%$, respectively. These data were in the range reported in a previous study (Paleari et al., 1998) which concluded that the range of moisture, protein and ash were 69.5 $-76.5 \%, 19.5-23.4 \% 1.0-1.5 \%$, respectively for raw mammalian and poultry muscle. On the other hand, Hoffman et al., (2005) reported that the proximate chemical composition of the same cut were 76.96, 21.65, 1.95 and $1.20 \%$ for moisture, protein, fat and ash respectively. Jones et al., (1995) reported

Table 1

Chemical composition of ostrich meat (Iliofibularis)

\begin{tabular}{cc}
\hline Component & \% (wet weight) \pm SE \\
\hline Moisture & $75.0 \pm 1.3$ \\
Protein & $22.4 \pm 1.4$ \\
Fat & $1.5 \pm 0.5$ \\
Ash & $1.1 \pm 0.2$ \\
\hline
\end{tabular}


that intramuscalar fat and moisture content in the Iliofibularis were in the renge of 0.94 and $76.55 \%$ respectively.

The chemical analysis of ostrich steaks treated with different natural antioxidants (AA, Toc and Ros) alone or in combination during the storage period at $4{ }^{\circ} \mathrm{C}$ for 21 days are depicted in Table (2) and reveal that natural antioxidants significantly affect the chemical analysis as follows:
AA exerted a definite pro-oxidant action in ground beef and the addition of $\alpha$-tocopherol showed a reduction rate of lipid oxidation in ground beef. Simillar results were obtained in turkey (Nam et al., 2003). In addition, a positive relation was observed between the level of $\alpha$-tocopherol and reducing rancidity in both cooked and uncooked patties of lamb and chicken (Abu Salem and Saad, 1991). In this concern, Lynch et al. (1999) found that the level of $\alpha-$ Toc $(200 \mathrm{ppm})$ resulted in the

Table 2

Changes in TBA (as mg malonaldehyde / $\mathrm{kg}$ meat) of ostrich steaks as affected by antioxidants during storage at $4{ }^{\circ} \mathrm{C}$ *

\begin{tabular}{|c|c|c|c|c|c|c|c|}
\hline \multirow{3}{*}{$\begin{array}{c}\text { Storage } \\
\text { period } \\
\text { (day) }\end{array}$} & \multicolumn{7}{|c|}{ TBA (malonaldehyde mg/kg meat) } \\
\hline & \multicolumn{7}{|c|}{ Treatments } \\
\hline & Control & AA & Toc & Ros & $\mathbf{A A}+\mathbf{T o c}$ & AA + Ros & Toc + Ros \\
\hline 0 & $\begin{array}{l}0.34^{\mathrm{s}} \\
\pm 0.00\end{array}$ & $\begin{array}{l}0.34^{\mathrm{s}} \\
\pm 0.00\end{array}$ & $0.34^{s} \pm 0.00$ & $\begin{array}{l}0.34^{\mathrm{s}} \\
\pm 0.00\end{array}$ & $\begin{array}{l}0.34^{\mathrm{s}} \\
\pm 0.00\end{array}$ & $\begin{array}{c}0.34^{\mathrm{s}} \\
\pm 0.00\end{array}$ & $\begin{array}{c}0.34^{\mathrm{s}} \\
\pm 0.00\end{array}$ \\
\hline 7 & $\begin{array}{c}0.86^{j} \\
\pm 0.00\end{array}$ & $\begin{array}{l}0.60^{\circ} \\
\pm 0.00\end{array}$ & $\begin{array}{l}0.68^{m} \\
\pm 0.00\end{array}$ & $\begin{array}{c}0.71^{\prime} \\
\pm 0.00\end{array}$ & $\begin{array}{l}0.50^{q} \\
\pm 0.00\end{array}$ & $\begin{array}{c}0.45^{r} \\
\pm 0.00\end{array}$ & $\begin{array}{l}0.50^{q} \\
\pm 0.00\end{array}$ \\
\hline 14 & $\begin{array}{c}1.92^{\mathrm{b}} \\
\pm 0.00\end{array}$ & $\begin{array}{l}0.82^{k} \\
\pm 0.00\end{array}$ & $\begin{array}{l}0.88^{h} \\
\pm 0.00\end{array}$ & $\begin{array}{l}0.91^{f} \\
\pm 0.00\end{array}$ & $\begin{array}{l}0.64^{m} \\
\pm 0.00\end{array}$ & $\begin{array}{l}0.50^{q} \\
\pm 0.00\end{array}$ & $\begin{array}{l}0.57^{p} \\
\pm 0.00\end{array}$ \\
\hline 21 & $\begin{array}{l}2.74^{\mathrm{a}} \\
\pm 0.00\end{array}$ & $\begin{array}{c}1.26^{\mathrm{e}} \\
\pm 0.00\end{array}$ & $\begin{array}{l}1.45^{\mathrm{d}} \\
\pm 0.00\end{array}$ & $\begin{array}{l}1.49^{\circ} \\
\pm 0.00\end{array}$ & $\begin{array}{c}0.92^{f} \\
\pm 0.00\end{array}$ & $\begin{array}{c}0.86^{\mathrm{i}} \\
\pm 0.00\end{array}$ & $\begin{array}{l}0.90^{\mathrm{g}} \\
\pm 0.00\end{array}$ \\
\hline
\end{tabular}

* Means having different superscript $(a, b, c, \ldots s)$ within each row or those within each column are significant different at $(P<0.01)$. AA: Ascorbic acid. Toc: $\alpha$-tocopherol. Ros: Rosemary.

It is clear that the data presented in Table (2) reveal that the TBA of the untreated sample (control) had increased significantly $(P<0.01)$ during storage at $4{ }^{\circ} \mathrm{C}$ for up to 21 days. On the other hand, the TBA values of the antioxidant-treated samples was insignificantly increased during storage, compared to the control samples (Table 2). Moreover, a significant $(P<0.01)$ reduction in TBA was found in the samples treated with antioxidant either alone or in combinations compared to the untreated control samples. Moreover, the effectiveness of different antioxidants on the TBA in ostrich meat could be arranged in the following order: $A A+$ Ros, Toc + Ros, AA + Toc, AA, Toc and Ros. These results indicated that the mixture of antioxidants was more effective in the reduction of TBA than the individual antioxidants. Moreover, the mixture of AA + Ros had a more significant effect on the reduction of lipid oxidation than the other antioxidants tested. These results suggested that both the individual and or the mixtures of antioxidants were effective in retarding lipid oxidation in ostrich meat steaks.

Lipid oxidation is one of the major causes of meat quality deterioration. The oxidation deterioration of the polyunsaturated lipids of foods leads to short-chain aldehydes, ketones and other oxygenated compounds through the formation of hydroperoxides, which are considered to be responsible for the development of rancidity in stored foods (Grau et al., 2000). Furthermore, lipid oxidation rates may be affected by the type and level of antioxidant as well as the method of treatment. Okayama et al., (1987) suggested that lowest TBA level which were packaged under vacuum and storage up to 270 days at $-20^{\circ} \mathrm{C}$ and dietary vit. $\mathrm{E}$ supplementation of cattle delayed lipid oxidation in beef (Lynch et al., 1999).

On the other hand, the addition of rosemary extracts in the current study significantly $(P<0.05)$ improved oxidative stability. Rosemary contains many compounds which have antioxidant properties identified as phenolic type compounds including rosmaridiphenol, rosmariqunone, rosmanol and carnosol (Houlihan and Ho, 1985). These compounds have free radical scavenger activity similar to butylated hydroxyanisole (BHA),butylated hydroxytoluene (BHT) or tertiary butylated hydroxyquinon (TBHQ). The addition of rosemary extract was reported to improve the oxidative stability of meat (Escalante et al., 2001; Fang and Wada, 1993). These authors speculated that rosemary extract may chelate metal ions, such as $\mathrm{Fe}^{+2}$, resulting in the reduction of the formation rate of activated oxygen. In this concern, Estevez et al. (2005) reported that the high effectiveness of antioxidants from natural resources against oxidative reactions showed similar activity to those from synthetic origin.

Antioxidant synergism in food systems has been studied in the recycling of $\alpha$-Toc and AA. Wong et al. (1995) found that the components of rosemary extract may be used as a substitute for ascorbic acid to enhance the antioxidative activity of $\alpha$-Toc. These authors added that samples of cooked beef containing herbal extracts (Rosmary and Sage) exhibited lower levels of malonaldhyde compared 
with control samples. Escalante et al. (2001) demonstrated that rosemary either alone or with ascorbic acid was highly effective in the inhibition of lipid oxidation (TBA) in beef patties. O'sulivan, (2004) stated that a mixture of $\alpha$-Toc and rosemary extract showed a stronger antioxidant effect than either of $\alpha$-Toc or Ros extract alone.

The results presented in Table (3) show the effect of antioxidants on the peroxide values of ostrich steaks during storage at $4{ }^{\circ} \mathrm{C}$. It could be noticed that a significant gradual increase in peroxide values was detected in all samples either with or without antioxidants during storage. However, it is clear from these data that the peroxide values of the untreated sample (control) were higher than that of the samples treated with different levels of antioxidants regardless of the storage period. Moreover, the mixtures of antioxidants had greater effects on peroxide compared to the individual antioxidants. The mixture of AA + Ros had the most significant effect on reducing the lipid oxidation, followed by Toc + Ros and AA + Toc. These results are in accordance with the results of Korimova et al. (1998), who reported that rosemary extract effectively inhibited the formation of PV in meat products. Similar to the current results, Verma and Sahoo, (2000) noted that PV decreased as the $\alpha$-tocopherol acetate level increased in the meat samples (ground chevron) up to $10 \mathrm{ppm}$ although beyond that, it again increased, resulting in a higher concentration of $\alpha$-toc because the acetate group blocks the activity of the molecule. This indicates that addition of $\alpha$-tocopherol acetate to meat samples at concentrations higher than $10 \mathrm{ppm}$ is not advantageous in terms of lipid peroxidation. Juntachote et al. (2006) reported that the stability of cooked ground pork treated with various antioxidants decreased in the following order: commercial antioxidant mixture $(0.3 \%$ citric acid $+0.5 \%$ ascorbic acid $+0.02 \% \alpha$-tocopherol) $>$ dried galangal powder $>$ dried holy basil powder $>$ ethanolic extracts of galangal $>$ ethanolic extracts of holy basil control.

The data presented in Table (4) indicate that the free fatty acids (oleic acid \%) of the fat extracted from ostrich meat (with or without antioxidants) significantly increased gradually as the storage period increase up to 21 days. On the other hand, the addition of an antioxidant, either alone or in mixtures, caused a significant reduction in the free fatty acids (oleic acid) compared to the untreated samples (control) during all storage periods. No significant differences were observed among the different types of antioxidants used in the current study. There is a proportional relation between lipolysis and storage periods in the different samples. The Initiation and accumulation of lipolysis may be related to the presence of microorganisms which could play an important role through lipolytic activity (Demeyer et al., 1974), although muscle and adipose tissue lipases may also be active.This means that the hydrolysis of lipids can occur during storage, which may lead to a noticeable loss in flavor compounds since it is expected that lipids are the source of many flavor compounds and some of them may also be formed from amino acids (Halvarson, 1973). These results demonstrated that the individual antioxidants or their mixtures are effective in retarding lipid oxidation in ostrich meat steaks

The data presented in Table (5) show the changes in pigment content (metmyoglobin \%) of ostrich meat steak during storage at $4{ }^{\circ} \mathrm{C}$. These data reveal that a significant $(P<0.01)$ graduall increase in Met Mb was observed in all samples either with or without antioxidants as the storage period increased. The present study also demonstrated the efficient role of AA, Toc and Ros to improve the color stability of ostrich steaks. The increases in Met Mb in the samples treated with antioxidants was significantly $(P<0.01)$ lower than that of the control sample throughout storage periods. These results indicate that the mixtures of antioxidants had a greater effect on reducing the Met $\mathrm{Mb}$ than individual antioxidants. The results also demonstrated that antioxidants or their mixtures are effective in retarding Met $\mathrm{Mb}$ in ostrich meat steak. Thus, it could be stated that the dipping of ostrich steaks in a mixture of antioxidants

Table 3

Changes in peroxide value (mq. / Kg extract fat) of ostrich steaks as affected by antioxidants during storage at $4{ }^{\circ} \mathrm{C}$ *

\begin{tabular}{cccccccc}
\hline $\begin{array}{c}\text { Storage } \\
\text { period } \\
\text { (day) }\end{array}$ & \multicolumn{9}{c}{ Peroxide value (mq. / Kg extract fat) } \\
Treatments
\end{tabular}

* Means having different superscript $(a, b, c, \ldots t)$ within each row or those within each column are significant different at $(P<0.01)$.

AA: Ascorbic acid. Toc: $\alpha$-tocopherol. Ros: Rosemary. 
Table 4

Changes in oleic acid content (\%) of extracted fat from ostrich steaks treated by antioxidants during storage at $4{ }^{\circ} \mathrm{C}^{*}$

\begin{tabular}{cccccccc}
\hline \multirow{2}{*}{$\begin{array}{c}\text { Storage } \\
\text { period (day) }\end{array}$} & \multicolumn{9}{c}{ Oleic acid \% Treatments } \\
\cline { 2 - 8 } & Control & AA & Toc & Ros & AA + Toc & AA + Ros & Toc + Ros \\
\hline \multirow{2}{*}{0} & $0.28^{\mathrm{i}}$ & $0.28^{\mathrm{i}}$ & $0.28^{\mathrm{i}}$ & $0.28^{\mathrm{l}}$ & $0.28^{\mathrm{i}}$ & $0.28^{\mathrm{i}}$ & $0.28^{\mathrm{i}}$ \\
& \pm 0.01 & \pm 0.01 & \pm 0.01 & \pm 0.01 & \pm 0.01 & \pm 0.01 & \pm 0.01 \\
7 & $0.41^{\mathrm{g}}$ & $0.37^{\mathrm{h}}$ & $0.38^{\mathrm{h}}$ & $0.37^{\mathrm{h}}$ & $0.36^{\mathrm{h}}$ & $0.35^{\mathrm{h}}$ & $0.36^{\mathrm{h}}$ \\
& \pm 0.01 & \pm 0.01 & \pm 0.01 & \pm 0.01 & \pm 0.01 & \pm 0.01 & \pm 0.01 \\
14 & $0.74^{\mathrm{d}}$ & $0.68^{\mathrm{ef}}$ & $0.70^{\mathrm{e}}$ & $0.68^{\mathrm{ef}}$ & $0.67^{\mathrm{ef}}$ & $0.66^{\mathrm{f}}$ & $0.67^{\mathrm{ef}}$ \\
& \pm 0.02 & \pm 0.01 & \pm 0.01 & \pm 0.01 & \pm 0.01 & \pm 0.01 & \pm 0.01 \\
\multirow{2}{*}{21} & $0.92^{\mathrm{a}}$ & $0.88^{\mathrm{bc}}$ & $0.90^{\mathrm{bc}}$ & $0.88^{\mathrm{bc}}$ & $0.87^{\mathrm{bc}}$ & $0.86^{\mathrm{c}}$ & $0.87^{\mathrm{bc}}$ \\
& \pm 0.01 & \pm 0.01 & \pm 0.01 & \pm 0.01 & \pm 0.01 & \pm 0.01 & \pm 0.01 \\
\hline
\end{tabular}

* Means having different superscript $(a, b, c, \ldots i)$ within each row or those within each column are significant different at $(P<0.01)$. AA: Ascorbic acid. Toc: $\alpha$-tocopherol. Ros: Rosemary.

can help in minimize Met $\mathrm{Mb}$ accumulation in meat tissues during the storage period.

It is well known that pigment in meat is very important for consumers. When the color of meat changes from bright red (oxymyoglobin) to brown (metmyoglobin), consumers discriminate against that product (Mitsumoto et al., 1991). The oxidation of oxymyoglobin to metmyoglobin is a chemical process that causes discoloration (Schaefer, 2002). The formation of Met Mb from Oxy Mb is positively correlated to lipid oxidation (Yin et al., 1993). Free radicals are neutralized by antioxidants before lipid oxidation propagates among highly unsaturated fatty acid in cellular and subcellular membranes (Machlin, 1984). This delay in the production of lipid oxidation breakdown products (e.g. peroxidase) may indirectly prolong the life of Oxy $\mathrm{Mb}$. In this regard, Lynch et al. (1999) and Verma and Sahoo, (2000) reported that vitamin E improved the color stability of beef and (ground chevon). In addition, Shivas et al. (1984) \& Mitsumoto et al., (1991) suggested that display life was extended when $A A$ was added to ground beef. Furthermore, Escalante et al. (2001) reported that rosemary, either alone or with ascorbic acid, was highly effective in inhibiting
Met $\mathrm{Mb}$ formation in beef patties. This may due to different types and concentrations of antioxidants.

The changes in viable bacterial counts of ostrich steaks with and or without natural antioxidants (AA, Toc and Ros) are shown in Table (6). These data show that the viable bacterial counts of all samples gradually increased during storage. At days 7, 14 and 21 , the bacterial counts of untreated samples (control) were higher than those in the antioxidanttreated samples with antioxidants except Toc and $\mathrm{AA}+$ Toc-treated samples. The present results indicated that the microbial counts were sufficiently low during the storage period in steaks treated with rosemary alone $\left(2.5 \times 10^{3}\right)$ and with Ros + AA $\left(2.1 \times 10^{3}\right)$ or Ros+Toc $\left(2.5 \times 10^{3}\right)$. The color of meat is used as an indicator of freshness although it is not a good indicator of freedom from microbial spoilage. In fact, discoloration occurs prior to microbial spoilage in fresh meat products (Schaefer, 2002). From a product wholesomeness perspective, microbial spoilage is more important than the lack of an appealing color. A long-standing challenge in meat science has been to extend the stability of the desirable bright red color of fresh beef to more fully capture the marketing opportunity that exists prior to

Table 5

Changes in metmyoglobin formation (\%) of ostrich steaks as affected by antioxidants during storage at $4{ }^{\circ} \mathrm{C}^{*}$

\begin{tabular}{cccccccc}
\hline \multirow{2}{*}{$\begin{array}{c}\text { Storage } \\
\text { period (day) }\end{array}$} & \multicolumn{7}{c}{ Metmyoglobin (\%) Treatments } \\
\cline { 2 - 8 } & Control & AA & Toc & Ros & AA + Toc & AA + Ros & Toc + Ros \\
\hline \multirow{2}{*}{0} & $5.15^{\mathrm{r}}$ & $5.15^{\mathrm{r}}$ & $5.15^{\mathrm{r}}$ & $5.15^{\mathrm{r}}$ & $5.15^{\mathrm{r}}$ & $5.15^{\mathrm{r}}$ & $5.15^{\mathrm{r}}$ \\
& \pm 0.01 & \pm 0.01 & \pm 0.01 & \pm 0.01 & \pm 0.01 & \pm 0.01 & \pm 0.01 \\
7 & $9.87^{\mathrm{k}}$ & $7.13^{\mathrm{p}}$ & $7.94^{\mathrm{m}}$ & $7.19^{\circ}$ & $7.03^{\mathrm{q}}$ & $7.00^{\mathrm{q}}$ & $7.10^{\mathrm{p}}$ \\
& \pm 0.01 & \pm 0.01 & \pm 0.02 & \pm 0.01 & \pm 0.01 & \pm 0.01 & \pm 0.01 \\
14 & $15.99^{\mathrm{b}}$ & $9.93^{\mathrm{j}}$ & $10.89^{\mathrm{g}}$ & $10.21^{\mathrm{i}}$ & $9.82^{\mathrm{l}}$ & $9.69^{\mathrm{m}}$ & $9.96^{\mathrm{j}}$ \\
& \pm 0.01 & \pm 0.01 & \pm 0.01 & \pm 0.01 & \pm 0.01 & \pm 0.01 & \pm 0.01 \\
\multirow{2}{*}{21} & $21.02^{\mathrm{a}}$ & $11.09^{\mathrm{e}}$ & $13.05^{\mathrm{c}}$ & $11.36^{\mathrm{d}}$ & $10.86^{\mathrm{g}}$ & $10.51^{\mathrm{h}}$ & $10.99^{\dagger}$ \\
& \pm 0.01 & \pm 0.01 & \pm 0.01 & \pm 0.01 & \pm 0.01 & \pm 0.01 & \pm 0.01 \\
\hline
\end{tabular}

${ }^{*}$ Means having different superscript $(a, b, c, \ldots r)$ within each row or those within each column are significant different at $(P<0.05)$. AA: Ascorbic acid. Toc: $\alpha$-tocopherol. Ros: Rosemary. 
Table 6

Changes in viable bacterial counts (c.f.u / g) of ostrich steaks as affected by antioxidants during storage at $4{ }^{\circ} \mathrm{C}$.

\begin{tabular}{cccccccc}
\hline \multirow{2}{*}{$\begin{array}{c}\text { Storage } \\
\text { period (day) }\end{array}$} & Control & AA & Toc & Ros & AA + Toc & AA + Ros & Toc + Ros \\
\cline { 2 - 7 }$y$ & $9.3 \times 10^{2}$ & $9.3 \times 10^{2}$ & $9.3 \times 10^{2}$ & $9.3 \times 10^{2}$ & $9.3 \times 10^{2}$ & $9.3 \times 10^{2}$ & $9.3 \times 10^{2}$ \\
7 & $1.9 \times 10^{3}$ & $1.6 \times 10^{3}$ & $1.8 \times 10^{3}$ & $9.8 \times 10^{2}$ & $1.8 \times 10^{3}$ & $9.9 \times 10^{2}$ & $10.1 \times 10^{2}$ \\
14 & $1.2 \times 10^{4}$ & $1.1 \times 10^{4}$ & $1.2 \times 10^{4}$ & $1.2 \times 10^{3}$ & $1.2 \times 10^{4}$ & $1.3 \times 10^{3}$ & $1.3 \times 10^{3}$ \\
21 & $3.2 \times 10^{4}$ & $3.1 \times 10^{4}$ & $3.1 \times 10^{4}$ & $2.5 \times 10^{3}$ & $2.4 \times 10^{4}$ & $2.1 \times 10^{3}$ & $2.5 \times 10^{3}$ \\
\hline
\end{tabular}

AA: Ascorbic acid. Toc: $\alpha$-tocopherol. Ros: Rosemary.

the time of microbial spoilage. Discoloration of fresh beef products has been very premature, relative to microbial spoilage (Schaefer, 2002). Similar results were obtained by Kesurreccion and Reynolds, (1990) who reported that the microbial counts of frankfurters treated with Ros extract or mixture of Ros + Toc were sufficiently low during the first 3 weeks of the tested period. On the other hand, the viable bacterial counts were not affected significantly with the addition of AA, Toc, or their mixtures to beef steak (Okayama et al., 1987). However, Shivas et al. (1984) reported that microbial counts were not affected by AA treatment.

In general, under aerobic conditions there is no obvious change in the meat until the bacterial count density exceeds $10^{8} / \mathrm{g}$ when spoilage odors and ammonia begin to be detected and a microbial count of $10^{7} / \mathrm{g}$ is an acceptable upper limit during the storage of meat and can therefore be regarded as the safety / quality limit (Kilsby, 1982).

It could be noticed that the panelists were able to clearly detect the differences in aroma quality, oxidative rancidity and changes in color of ostrich steaks treated with antioxidants, compared with untreated samples after 14 and 21 days of storage at $4{ }^{\circ} \mathrm{C}$. On the other hand, the presence of antioxidants either in separate or in mixture form extended the changes in odor and color of ostrich meat with score (1) even after 21 days of storage. Moreover, untreated samples reached the highest value corresponding to smell (score 3) and 10-20\% of discoloration (score 3), as early as 21 days. These results were in agreement with those obtained by Barbut et al. (1985) who found that Ros inhibited undesirable odor appearance in Turkey sausage stored at $4{ }^{\circ} \mathrm{C}$. Also, these results were in harmony with those recorded by Escalante et al. (2001) who showed that Ros alone or with AA, extended the fresh beef patty odo during storage time. Organoleptic evaluation revealed that the level of Toc (200 ppm) led to slow rancidity in cooked lamb patties which were packaged under atmospheric pressure (Abu-Salem and Saad, 1991). The results of sensory evaluation were in agreement with those found for lipid oxidation as revealed by the TBA, PV and for Met $\mathrm{Mb}$ formation discussed before.

\section{CONCLUSIONS}

It could be concluded that the use of natural antioxidant mixtures in ostrich meat such as AA +
Toc, AA + Ros and Toc + Ros especially at the level $0.05 \%$ L-ascorbic acid, $0.05 \%$ rosemary extract and $0.08 \%$ DL- $\alpha$-tocopherol effectively reduce the oxidative deterioration of lipids, retard the development of rancidity, minimize metmyoglobin formation and microbiological deterioration of meat, stored at $4{ }^{\circ} \mathrm{C}$ for 21 days. These antioxidants can be used effectively for stored meat.

\section{REFERENCES}

Abu-Salem M Ferial, Saad M.M. 1991. An inhibition of TBA formation in cooked and uncooked lamb and chicken patties using Alpha-Tocopherol. 37 th International Congress of Meat Science, and Technology, vol., 2 Kulmbach, Germany.

AOAC. 1995. "Official methods of analysis" 14 th ed. Association of Official Analytical Chemists Washington. D.C.

Barbut S, Josephson DB, Maurer AJ.1985. Antioxidant properties of rosemary oleoresin in turkey sausage. $J$. Food Science 50, 1356-1359, 1363.

Bligh, EC, Dyer WJ. 1959. A rapid method of total lipid extraction and purification. Com. J. Biochemistry, Phsic. 37, 911-917.

Chen $\mathrm{CH}$, Pearson AM, Gray JI. 1992. Effects of synthetic antioxidants (BHA, BHT AND PG) on the mutagenicity of IQ-like compounds. Food Chemistry 45, 177-183.

Demeyer D, Hoozee J, Mesdom H. 1974. Specificity of lipolysis during dry sausage ripening J. Food Science 39, 293-296.

Djenane D, Escalante AS, Beltran JA, Roncales P. 2001. Ability of $\alpha$-Tocopherol, taurine and rosemary, in combination with vitamin $\mathrm{C}$, to increase the oxidative stability of beef steaks packaged in modified atmosphere. Food Chemistry 76, 407-41€5.

Dorman HJD, Peltoketo A, Hiltunen R, Tikkanen MJ. 2003. Characterisation of the antioxidant properties of de-odourised aqueous extracts from selected Lamiaceae herbs. Food Chemistry 83, 255-262.

Escalante AS, Dienane D, Torrescano G, Beltran JA, Roncales P. 2001. The effects of ascorbic acid, taurine, carnosine and rosemary powder on colour and lipid stability of beef patties packaged in modified atmosphere. Meat Science 58, 421-429.

Escalante A, Djenane D, Torrescano G, Beltran JA, Roncales P. 2003. Antioxidant action of borage, rosemary, oregano and ascorbic acid in beef patties packaged in modified atmosphere. J. Food Science 68, 339-344.

Estevez M, Ramirez R, Ventanas S, Cava R. 2005. Sage and rosemary essential oils versus BHT for 
the inhibition of lipid oxidative reactions in liver. Food Science and Techenology.

Fang X, Wada S. 1993. Enhancing the antioxidant effect of $\alpha$-Tocopherol with rosemary in inhibiting catalyzed oxidation caused by $\mathrm{Fe}^{+2}$ and hemoprotein. Food Research International 26, 405-411.

Grau A, Guardiola F, Boatella A, Codony R. 2000. Measurement of 2-thiobarbituric acid values in dark chicken meat through derivative spectrophotometer. J. Agriculture Food Chemistry 48, 1155-1159.

Halvarson H. 1973. Formation of lactic acid, volatile fatty acids and nautral. Volatile monocabonyl compounds in swedish fermented sausage. J. Food Science 38, 310.

Hoffman LC, Joubert M, Manley M. 2005. The effect of dietary fish oil rich in n-3 fatty acids on the organoleptic, fatty acid and physicochemical characteristics of ostrich meat. Meat Science 70, 45-53.

Houlihan CM, C Ho T. 1985. Natural Antioxidants. Ch. 6. In Flavor Chemistry of Fats and Oils, D. B, Min and T. H. Smouse, (Fd.), 117. American Oil Chemists Society Champaign, IL. PP

Ibanez E, Kubatova A, Senorans FJ, Cavero S, Reglero G, Hawthorne SB. 2003. Subcritical water extraction of antioxidant compounds from rosemary plants, $J$. Agriculture Food Chemistry 51, 375-382.

IMFN. 2000. Institute of Medicine, Food and Nutrition Board. Standing Committee on the Scientific Evaluation of Dietary Reference Intakes. Dietary Reference Intakes for vitamin C, vitamin E, Selenium, and Carotenoids. Washington, D. C., National Academy Press.

IMFN. 2001. Institute of Medicine, Food and Nutrition Bord. Standing Committee on the Scientific Evaluation of Dietary Reference Intakes. for vitamin A, vitamin $\mathrm{K}$, Arsenic, Boron, Chromium, Copper, Iodine, Iron, Manganese, Molybdenum, Nickel, Silicon, Vanadium, and Zinc. Washington, D. C. National Academy Press

Jo C, Jin SK, Ahn DU. 2000. Color changes in irradiated cooked pork sausage with different fat sources and packaging during storage. Meat Science 55, 107-113.

Jones SDM, Robertson WM, Brereton D. 1995. The ostrich as a meat animal. Canadian Ostrich 4,18-20.

Juntachote T, Berghofer E, Siebenhandl S, Bauer F. 2006. The antioxidative properties of holy basil and galangal in cooked ground pork. Meat Science $\mathbf{7 2}$, 446-456.

Kesurrection AVA, Reynolds AE. 1990. Evaluation of natural antioxidants in frankfurters containing chicken and pork. J. Food Science 55, 629-631.

Kilsby DC. 1982. In: Meat microbiology [Brown, M. H. (Ed.)], Science Publishers, London, New York, 387.

Korimova L, Mate D, Turek P. 1998. Influence of natural antioxidants on heat-untreated meat products quality. Czech. J. Food Science 18 (4) 124-128.

Lynch MP, Kerry JP, Buckley DJ, Faustman C, Morrissey PA. 1999. Effect of dietary vitamin E supplementation on the colour and lipid stability of fresh, frozen and vacuum packaged beef. Meat Science 52, 95-99.

Machlin LJ. 1984 Vitamin E. In L. Machlin (Ed), Handbook of vitamins (p. 99). New York: Marcel Dekker.

Mitsumoto M, Cassens RG, Schaefer DM, Scheller KK. 1991. Pigment stability improvement in beef steak by ascorbic acid application. J. Food Science 56, 857858.

Morrissey PA, Sheehy PJA, Galvin K, Kerry JP, Buckley DJ. 1998. Lipid stability in meat and meat products. Meat Science 4, S73-S86.

Nam KC, Min BR, Yan H, Lee EJ, Mendonca A, Wesley I, Ahn DU. 2003. Effect of dietary vitamin E and irradiation on lipid oxidation, colour, and volatiles of fresh and previously frozen turkey breast patties. Meat Science 65, 513-521.

O'sulivan CM, Lynch AM, Lynch PB, Duckley DJ, Kerry JP. 2004. Use of antioxidants in chicken nuggets manufactured with and without the use of salt and / or sodium tripolyphosphate: Effect on product quality and shelf-life stability. International J. Poultry Science 3, 345-353.

Okayama T, Imai T, Yamanous M. 1987. Effect of ascorbic acid and alpha-tocopherol on storage stability of beef steaks. Meat Science 21, 267-273.

Pearson D. 1968. Application of chemical methods for the assessment of beef quality. III. Methods related to fat spoilage J. Science \&. Food. Agriculture 19, 553.

Sales T. 1996. Histological, Biophysical, Physical and Chemical Characteristics of Different Ostrich Muscles. J. Science \& Food Agriculture 70, 109-114.

SAS. 1998. SAS / STAT user's Guide Release 6.03 Edition, SAS Institute Inc., Cary INc, USA.

National D. M. Cattlemen's Beef Association and the Cattlemen's Beef Board.

Shivas SD, Kropf DH, Hunt MC, Kastner CL, Kendall JLA, Dayton AD. 1984. Effects of ascorbic acid on display life ground beef. J. Food Protection 47, 11 .

Verma SP, Sahoo J. 2000. Improvement in the quality of ground chevon during refrigerated storage by tocopherol acetate preblending. Meat Science 56, 403-413.

Wong JW, Hashimoto K, Shibamoto T. 1995. Antioxidant activities of rosemary and sage extracts and vitamin $\mathrm{E}$ in a model system. J. Agriculture \& Chemistry 43, 2707-2712.

Yin MC, Faustman C, Riesen JW, Williams SN. 1993. The effects of $\alpha$-tocopherol and ascorbate upon oxymyoglobin and phospholipid oxidation. J. Food Science 58, 1273-1276.

Zaika LL, Zell TE, Smith JL, Palumbo SA, Kissinger JC. 1976. The role of nitrite and nitrate in Lebanon Bologna, a fermented sausage. J. Food Science 41, 1457.

Recibido: 2/4/09 Aceptado: $11 / 9 / 09$ 